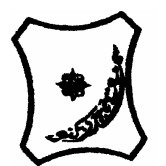

Bayero Journal of Pure and Applied Sciences, 6(2); $19-22$

Received: June 2013

Accepted: November 2013

ISSN 2006 - 6996

\title{
UTILIZATION OF CYPERMETHRIN BY BACTERIA ISOLATED FROM IRRIGATED SOILS
}

*Shamsuddeen U. and Inuwa A. B.

${ }^{1}$ Department of Microbiology Bayero University, Kano Nigeria.

*Correspondence author: msdeen1@yahoo.com

\begin{abstract}
Soil bacteria capable of utilizing Cypermethrin as a source of carbon were isolated using enrichment technique. The bacteria were Psuedomonas aeruginosa, Serratia spp Micrococcus sp, Staphylococci and Streptococcus sp. Growth of P. aeruginosa was determined in the presence of

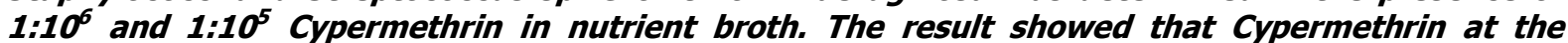
concentration of 1:10 stimulated the growth of the bacterium faster than 1:10 concentration of the pesticide and the control (nutrient broth not blended with the pesticide).
\end{abstract}

Keywords: Cypermethrin, soil, enrichment, bacteria, Pseudomonas aeruginosa.

\section{INTRODUCTION}

Pesticides are used worldwide to destroy or mitigate pests both in agricultural and domestic settings. The world has kept witnessing the evolution of newer synthetic pesticides most of which have the desirable pesticidal activity. However, most people who employ the use of such pesticides especially in developing countries know very little about their effects on the environment, humans, aquatic lives and wildlife. Of the varieties of synthetic chemical pesticides available, Pyrethroids are among the most common. They are effective against flies, mosquitoes, stored grain insects, aphids, e.t.c. Cypermethrin is a fourth generation Pyrethroid pesticide that was first synthesized in 1974 and is particularly more effective against the moth pests of cotton, fruits and vegetable crops. It works by quickly affecting the insect's nervous system (NPIC, 1998). Cypermethrin is highly toxic to fish, bees and water insects and very low in toxicity to birds. Toxicity to humans is dependent upon the frequency of exposure. People working with Cypermethrin sometimes develop tingling, burning, and itching (NPIC, 1998).

In the soil, Cypermethrin has a half-life of 30 days, although the half-life can range from 2 to 8 weeks (USEPA, 2005). Soil microbes rapidly break down Cypermethrin (USEPA, 2005, cited in NPIC, 1998). Cypermethrin has an extremely low potential to move in the soil. It is unlikely to contaminate groundwater because it binds tightly to soil particles (USEPA, 2005, cited in NPIC, 1998). Cypermethrin is stable in sunlight (NPIC, 1998). Varieties of physical chemical and biological methods are available for the treatment of soil that has been contaminated with organic wastes (pesticides inclusive). Among this however, the biological option (bioremediation) is the most effective and also the cheapest. Soil microorganisms adopt the pesticide molecule as the source of carbon and energy and this result either in the conversion of the pesticide to non-toxic intermediate or the complete mineralization of the pesticide molecule. Majid et al. (2012) isolated from surface soil five different bacteria capable of degrading Cypermethrin under laboratory conditions. The bacteria were identified as Psuedomonas aeruginosa,. P. fluorescens, Bacillus licheniformis, Alcaligenes sp. and Corynebacterium sp. Higher degrading ability as reported was found among $P$. aeruginosa, $P$. fluorescens, and Bacillus licheniformis. Similarly, Murugesan et al. (2009) demonstrated the ability of soil bacteria isolated from Brinjal cultivated soils to utilize Cypermethrin as a source of carbon. The bacteria were $P$. aeruginosa, Klebsiella sp, Escherichia coli, Bacillus sp, Corynebacterium sp, Alcaligenes sp and Serratia sp. Higher Utilization and degrading ability was found among $P$. aeruginosa, Klebsiella sp, and $E$. coli. The present study aims at isolating from Kwakwachi irrigated soils, those bacteria capable of utilizing Cypermethrin as a source of carbon and also to bring into light the utilization pattern in the presence of varying concentrations of the Cypermethrin as exhibited by a selected Cypermethrin-utilizing bacterium.

\section{MATERIALS AND METHODS}

\section{Collection of soil samples}

The soil samples were collected at different time intervals from Kwakwachi irrigated soils Kano (located adjacent to and behind infectious diseases hospitals Kano). These fields had already been sprayed with Cypermethrin for 3-4 years. The sampling procedure combined the procedures described by Murugesan et al. (2009) and Zalewski. Soil sub-samples were collected randomly at different sites of the field using sterile scalpel and the sub-samples collected were then gathered together in a single sterile dark polythene bag and then mixed together to form a uniform homogenous mixture i.e. the composite sample. This was then kept in a flask containing ice block and transported to the laboratory for further processing. 
Isolation and maintenance of Cypermethrin-utilizing bacteria

Mineral salt (MS) medium was used for the isolation of Cypermethrin-degrading bacteria. The medium has the following composition as recommended by Focht (2008) and Malghani et al. (2002).

$\begin{array}{ll}\text { Salt } & \text { Quantity } \mathbf{( g l}^{\mathbf{- 1}} \\ \mathrm{K}_{2} \mathrm{HPO}_{4} & 0.225 \\ \mathrm{KH}_{2} \mathrm{PO}_{4} & 0.225 \\ \left(\mathrm{NH}_{4}\right)_{2} \mathrm{SO}_{4} & 0.225 \\ \mathrm{MgSO}_{4} \cdot 7 \mathrm{H}_{2} \mathrm{O} & 0.050 \\ \mathrm{CaCO}_{3} & 0.005 \\ \mathrm{Fecl}_{2} & 0.005\end{array}$

The mixture above was supplemented with $1 \mathrm{ml}$ of trace minerals solution having the following composition.

$\begin{array}{ll}\text { Salt } & \text { Quant } \\ \mathrm{MnSO}_{4} \cdot \mathrm{H}_{2} \mathrm{O} & 0.169 \\ \mathrm{ZnSO}_{4} .7 \mathrm{H}_{2} \mathrm{O} & 0.288 \\ \mathrm{CUSO}_{4} \cdot 5 \mathrm{H}_{2} \mathrm{O} & 0.250 \\ \mathrm{NiSO}_{4} \cdot 6 \mathrm{H}_{2} \mathrm{O} & 0.026 \\ \mathrm{CoSO}_{4} & 0.028 \\ \mathrm{Na}_{2} \mathrm{MoO}_{4} \cdot 2 \mathrm{H}_{2} \mathrm{O} & 0.024\end{array}$

$\mathrm{pH}=7.2 \pm 0.2$

The flask was then gently shaken in order to mix the contents. It was then autoclaved at $121^{\circ} \mathrm{C}$ for 15 minutes. For MS - Agar, $15 \mathrm{~g}$ plain agar (agar - agar) was added to each $1000 \mathrm{ml}$ of the MS - medium before autoclaving. The soil sample was first of all sifted through appropriate sterile mesh sieve in order to remove stones and plant materials. Ten grams $(10 \mathrm{~g})$ of the sifted soil sample was then added aseptically into a conical flask containing $100 \mathrm{ml}$ of sterile MS-broth. This was then shaken gently and then incubated in a rotary shaker at a speed of 150 $\mathrm{rpm}$ and temperature of $30^{\circ} \mathrm{C}$ for $3-4$ days. The flask was left for few hours in order to allow the soil particles to settle. The suspension was then used to inoculate individual tubes containing MS-broth blended with the appropriate pesticide in the concentration range of $1: 10^{3}$ to $1: 10^{7}$ by aseptic transfer of $1 \mathrm{ml}$ of the suspension to $10 \mathrm{ml}$ of MS - pesticide tube. The tubes were labeled appropriately and incubated at room temperature for 2 days. To obtain pure culture, the tubes were centrifuged at $3000 \mathrm{rpm}$ for 5 mins and the cell pellets were then resuspended in $2 \mathrm{ml}$ of appropriate sterile media. These were incubated for 24 hours. Aliquot from each culture was then inoculated onto a plate containing MS-Agar blended with the appropriate concentration of the pesticide. The plates were then incubated under aerobic conditions at room temperature until discrete colonies were formed. Nutrient agar slant of each isolated organism was prepared and kept in a refrigerator at $0^{\circ} \mathrm{C}$ until further use.

\section{Characterization of the isolated bacteria}

The individual colonies were characterized into respective genera (and species in some cases) using a combination of morphological, microscopic, biochemical and differential tests as described by

\section{Growth kinetics studies of Cypermethrin- utilizing bacteria}

The selection of the bacterium ( $P$. aeruginosa) used in this assay procedure out of the different bacteria isolated was based on its rapid growth on mineral salt agar blended with Cypermethrin. The procedure as employed by Murugesan et al. (2009) and Majid (2012) et al. with some modifications was adopted. Viable cell counts of the bacterial cultures with and without the addition of pesticide were taken at regular intervals of time. Larger and rapidly growing colonies were selected for the study. The inoculum was standardized by comparison with Mac Farland's solution and then $5 \mathrm{ml}$ volume was inoculated into individual flasks containing $45 \mathrm{ml}$ sterile nutrient broth blended with Cypermethrin in the concentration range of $1: 10^{5}$ and $1: 10^{6}$. Control culture (containing no pesticide) was also prepared. Serial dilution $\left(10^{-1}\right.$ to $10^{-7}$ ) of the cultures was carried out at 0, 2, 6 and 24 hours of incubation. This was achieved by aseptically transferring $1 \mathrm{ml}$ of the culture into a tube containing 9 $\mathrm{ml}$ of $(0.85 \%)$ physiological saline. One millilitre $(1 \mathrm{ml})$ and $0.1 \mathrm{ml}$ aliquots were aseptically transferred into sterile and appropriately-labeled duplicate petridishes. This was followed by the addition of sterile molten nutrient agar. The petridishes were swirled gently on a flat surface so as to distribute the inoculum uniformly. The inoculated petridishes were then incubated at room temperature for $24 \mathrm{hrs}$ after which the colonies formed were counted.

\section{RESULTS}

Physicochemical parameters of the soil samples showed that $\mathrm{pH}$, temperature, organic matter and moisture content are $6.80-8.08,24-28^{0}, 2.4-5.81 \%$, and 8.3-14 respectively as presented in table 1 . 
Table 1: Physicochemical parameters of the soil samples

\begin{tabular}{ll}
\hline Parameter & Value \\
\hline $\mathrm{pH}$ & $6.80-8.08$ \\
Temperature & $24-28^{\circ} \mathrm{C}$ \\
Organic matter & $2.4-5.81 \%$ \\
Moisture content & $8.3-14 \%$ \\
\hline
\end{tabular}

The frequency of occurrence of Cypermethrin-utilizing bacteria showed Micrococcus $\mathrm{sp}$, $P$. aeruginosa, and $S$. mercescens with a total number of $2(14.29 \%), 7(35.71 \%)$, and $3(21.43 \%)$, respectively as presented in table 2 .

Table 2: Frequency of Occurrence of Cypermethrin-utilizing bacteria.

\begin{tabular}{lcc}
\hline Bacteria & Number & Percentage (\%) \\
\hline Micrococcus sp & 2 & 14.29 \\
Psseudomonas aeruginosa & 7 & 35.71 \\
Serratia mercescens & 3 & 21.43 \\
Staphylococcus aureus & 1 & 7.15 \\
Other staphylococci & 2 & 14.29 \\
Streptococcus sp & 1 & 7.15 \\
Total & $\mathbf{1 6}$ & $\mathbf{1 0 0}$ \\
\hline
\end{tabular}

The growth pattern (viable count) of $P$. aeruginosa in the presence of varying doses of Cypermethrin showed a count of $8.0 \times 10^{8} \mathrm{cfu} / \mathrm{ml}, 1.4 \times 10^{9} \mathrm{cfu} / \mathrm{ml}, 9.0 \times 10^{8} \mathrm{cfu} / \mathrm{ml}$ at $1: 100000,1: 1000000$ Cypermethrin concentration and control cultures and at $0 \mathrm{hr}$ respectively as shown in table 3.

Table 3: Growth pattern (viable count) of $\boldsymbol{P}$, aeruginosa in nutrient broth blended with varying concentrations (doses) of Cypermethrin.

\begin{tabular}{llll}
\hline Time (hr) & $\begin{array}{c}\text { Pesticide concentration } \\
\mathbf{1 : 1 0 0 0 0 0} \\
\end{array}$ & $\mathbf{1 : 1 0 0 0 0 0 0}$ & Control \\
\hline 0 & $\begin{array}{l}\text { Viable count(cfu/ml) } \\
2.0 \times 10^{8}\end{array}$ & $1.4 \times 10^{9}$ & \\
\hline 4 & $8.0 \times 10^{8}$ & $1.0 \times 10^{9}$ & $9.0 \times 10^{8}$ \\
6 & $1.7 \times 10^{9}$ & $1.9 \times 10^{9}$ & $2.2 \times 10^{8}$ \\
24 & $1.57 \times 10^{10}$ & $7.0 \times 10^{9}$ & $9.6 \times 10^{9}$ \\
\hline
\end{tabular}

\section{DISCUSSION}

This work has shown the involvement of various bacteria in the utilization of Cypermethrin as a sole carbon source. The bacteria (as shown in Table 2) range from Gram positive cocci to Gram negative rods. However, gram negative rods were isolated most frequently $(P$. aeruginosa $35.71 \%$, and $S$. mercescens $21.43 \%$ of the total bacteria isolated) accounting for approximately $57 \%$. However, among the total bacteria isolated, $P$. aeruginosa is the most dominant $(35.71 \%)$. These findings agree with that of Murugesan et al. (2009) where they showed that gram negative rod -shaped bacteria accounted for $87.5 \%$ of Cypermethrin utilizing - bacteria isolated from Brinjal cultivated soil. Additionally, they showed that $P$. aeruginosa was the most dominant $(60.4 \%)$. Grant et al. (2002) also showed the Cypermethrin and Flumethrin degrading ability of two bacteria belonging to the genera Psuedomonas and Serratia.

The growth kinetics study reveals the growth pattern of $P$. aeruginosa. In the present study, the bacterium exhibited different responses to different pesticide concentrations. The growth rate when compared with the control either increases or slightly decreases in the presence of the pesticide.

The viable counts of $P$. aeruginosa as presented in Table 3 show that cell count remains almost temporarily unchanged until $4 \mathrm{hrs}$. For instance at $1: 10^{6}$ Cypermethrin concentration, the count was $1.4 \times 10^{9} \mathrm{cfu} / \mathrm{ml}$ at $0 \mathrm{hr}, 1.0 \times 10^{9} \mathrm{cfu} / \mathrm{ml}$ at $2 \mathrm{hr}$ and $1.9 \times 10^{9} \mathrm{cfu} / \mathrm{ml}$ at $4 \mathrm{hrs}$. This indicates that throughout that period the cells were in the period of acclimatization or adjustment to the new environment i.e. the lag phase of growth. Beyond $4 \mathrm{hrs}$, the cells entered the phase of accelerated rapid growth i.e. the log or exponential phase of growth, where the count rose to $7.0 \times 10^{9} \mathrm{cfu} / \mathrm{ml}$. At $24 \mathrm{hrs}$, the count escalated to $3.08 \times 10^{10} \mathrm{cfu} / \mathrm{ml}$.

Comparison of the cell counts of $P$. aeruginosa cultures at $24 \mathrm{hr}$ shows higher cell count $\left(5.41 \times 10^{10} \mathrm{cfu} / \mathrm{ml}\right)$ in $1: 10^{5}$ Cypermethrin culture as compared with $3.08 \times 10^{10} \mathrm{cfu} / \mathrm{ml}$ at $1: 10^{6}$ Cypermethrin dilution and $3.90 \times 10^{9} \mathrm{cfu} / \mathrm{ml}$ in control. This shows that Cypermethrin at a concentration of $1: 10^{5}$ promotes/stimulates the growth of $P$. aeruginosa.

These findings supported the work of Majid et al. (2012) who showed that within some limits, the presence of Cypermethrin accelerates the growth of $P$. aeruginosa as compared with the control under the same conditions. The findings also supported those of Murugesan et al. (2009) who showed that among the Cypermethrin-utilizing bacteria isolated from Brinjal cultivated soils, $P$. aeruginosa ranks among those with the highest degrading ability. 


\section{Conclusion}

It can be concluded that bacteria capable of utilizing Cypermethrin as source of carbon exist in Kwakwachi irrigated soils. Additionally, within some limits, the pesticide can be said to be growth-promoting to $P$. aeruginosa. Similarly, it is evident that $P$. aeruginosa can serve as an ideal tool for mitigating environmental contamination due to Cypermethrin and possibly other pesticides.

\section{REFERENCES}

Cheesbrough, M (2005). District Laboratory Practice in Tropical Countries Part 2, UK. Cambridge University Press, Pp. 56, 64-65, 69-70.

Focht, D.D. (2008). 'Microbiological procedures for Biodegradation Research' in Weaver, R.W., Grant, R.J., Daniel, T.J. and Betts, W.B. (2002). 'Isolation and Identification of Synthetic Pyrethroid degrading bacteria. Journal of Applied Microbiology 92: 534 540.

Majid, M.R., Pahlaviani, K., Massiha, A. Issazadeh, K. and Muradov, P.N (2012). 'Biodegradation of cypermethrin by using indigenous bacteria isolated from surface soil.' $201222^{\text {nd }}$ International Conference on Environment and Industrial Innovation. 35.

Malghani, S., Nivedeta, S., Hu xue yu, Z. (2009). 'Isolation and identification of Profenophos-

\section{Recommendations}

This study reveals the biodegradability of Cypermethrin, however further studies are needed to reveal how environmental conditions such as differences in soil type do affect the degradation process.

$$
\text { degrading bacteria',Brazilian journal of }
$$
microbiology,40 (4): pp 1-5.

Murugesan, A.G., Jeyasanthi, T. and Maheswari, S. (2009). 'Isolation and Characterization of Cypermethrin utilizing bacteria from Brinjal cultivated soil', African Journal of Microbiology Research, 4 (1): $10-13$.

National Pesticide Information Centre (1998). Cypermethrin, Oregon State University. [online]. available: npici-orst.edu. Pp 1 - 5 [accessed, 24 November, 2011].

United States environmental protection agency (2005).what is a pesticide?

Zalewski J. (n.d). Sample Collection and Storage, Soil Microbiology. Biol/CSES 4684. Online. available:

http://firebox.vt.edu/users/chargedor/biol 46 84/methods/sample.htm/ Pp. 1-4. [accessed, 27 June, 2011]. 